\title{
1. Setting the agenda
}

Two events in 1971 and 1972 radically changed the context of British macroeconomic policy-making. First, in September 1971 the Bank of England implemented a set of reforms known as Competition and Credit Control (CCC), which ended quantitative restrictions on bank lending. These quantitative restrictions had been in force for most of the period since 1945, with the purpose of keeping the growth of credit consistent with Britain's exchange rate commitment (i.e., the fixed exchange rate between the dollar and the pound at $\$ 2.80$ from 1949 to 1967 , and at $\$ 2.40$ from 1967 to 1971 ). But they had been crude and inefficient, and were widely believed to have distorted the financial system. They required the banks to limit their lending to a particular figure at a particular date, regardless of customers' demands for finance or the banks' own preparedness to supply credit. The second was Britain's departure in June 1972 from the European 'snake', which had fixed the exchange rates between a number of currencies (notably the Deutschmark and French franc) in a narrow, snake-like band. The snake had been designed to maintain currency stability in Europe despite the breakdown of the previous Bretton Woods system, in which exchange rates had been pegged to the dollar.

By abandoning the use of administrative controls in monetary policy, the CCC reforms raised new questions about how monetary policy should be conducted. Most observers agreed that the level of interest rates, which was set by the Bank of England, would become a more important instrument, perhaps the most important instrument of all. But was it sufficient to relate interest rates to ultimate target variables such as inflation? Or could a case be made for an intermediate target specified in terms of the money supply?

The decision to leave the snake inaugurated almost 20 years of floating exchange rates. This also raised new questions about the conduct of monetary policy. Traditionally, the Bank of England had varied interest rates mostly in order to keep the pound stable on the foreign exchanges, with only a sideglance at the effects of interest rate variations on domestic economic activity. But in an era of floating exchange rates the exchange rate no longer provided a reliable guide to interest rate decisions. What should guide interest rates instead? Was the quantity of money (the sum of notes, coin and bank depos- 
its in the economy) appropriate as a target? Or should the exchange rate still have a role, even if secondary to the money supply?

These were some of the questions I tried to answer in two articles in The Times on 2 July 1975 and 19 January 1976. It needs to be emphasized that they were written when the annual inflation rate was well over 20 per cent and when memories of the collapse in share prices in 1974 were still vivid. In this environment a fixed exchange rate (against the currencies of countries with inflation under 10 per cent) would have been folly, while nominal interest rates had lost much of their signalling function for policy-makers. Money supply targets seemed to me to be the right policy response.

\section{Money Supply Targeting vs Interest Rate Targeting}

From an article 'The money supply - more meaningful than interest rates as a policy goal' in The Times, 2 July 1975.

The argument of the article was that interest rate targeting - in the sense of holding interest rates steady in order to give stability to asset prices and the financial system - is inappropriate in an inflationary economy. Entrenched and volatile inflationary expectations make it difficult to know what level of interest rates is most appropriate to achieve desired macroeconomic objectives. In such circumstances money supply targeting is 'plainly much more sensible', since a target set slightly 'beneath the going rate of inflation' should in due course 'bring inflation down without disturbing financial markets more than necessary'.

The article said that 'a new style of monetary policy [i.e., British monetarism, with money supply targets] has gradually developed which...may result in big improvements in stabilization policy in future'. In view of the adoption of money supply targets in the following year and the progress in inflation over the next ten years, this was a good surmise. (See 'A perspective on a decade of progress' on pp. 111-14.)

Cynics might claim that the sole objective of central banks is to minimize criticism. If so, the Bank of England has failed lamentably in recent years. Few institutions have been attacked so frequently or so strongly. The official memoirs industry will no doubt thrive on future disclosures about the conduct of monetary policy during the 'Barber boom' of 1972 and 1973 when the money supply exploded upwards by 25 per cent a year. The question 'how could it have happened?' has become almost an opening gambit of conversation between economists. It is a way of recognizing like-minded people. 
There may now be unanimity that the rates of monetary expansion found in 1972 and 1973 must never be repeated. But has the Bank of England mended its ways? Has it learnt lessons of permanent value from recent unhappy experiences? It will be argued here that the Bank has been forced by the pressure of events to modify its approach to monetary control. As long as there is no back-sliding for reasons of political expediency, the traumas of the Barber boom have had a beneficial effect by exposing the errors contained in some ancient and highly durable banking prejudices. A new and better style of monetary policy has gradually developed. It may result in big improvements in stabilization policy in future.

But, before presenting this argument, two basic truths have to be noted. They are not controversial, but tend to be forgotten in the heat of debate. The first is that one of the Bank of England's main functions is to oversee and manage the Government's finances. It has to ensure that, if the Government is spending more than it is receiving in taxation, the deficit is covered by borrowing from other agents in the economy.

Secondly, money supply targets and interest rate policy have to be consistent. A particular money supply target requires that interest rates be set at a certain level, and a particular interest rate policy involves certain money supply behaviour. One entails the other and vice versa. For example, the Bank of England cannot clamp down on money supply growth and hope that interest rates will not rise. The financial system will find that because of official policy it does not have enough liquidity to meet the demands placed on it by trade and industry. It must therefore raise interest rates to hold back that demand. If the Bank of England tries to stop this normal commercial response by artificial restrictions on lending, it is liable to distort financial markets and discourage competition.

The interaction between interest rates and money supply policy suggests alternative styles of monetary control. One approach, which might be called the 'new style', is to emphasize the money supply as the vital target variable. This approach is found in the United States and West Germany, where the central banks announce in advance a target for money supply growth. Although mindful of interest rate movements, they do not allow immense government borrowing needs to frighten them from large bond sales if necessary. This policy can be partly justified on the grounds that, if interest rates go up, the industrial demand for loans will be choked off. Because of the extra room created in the economy, a large budget deficit may not cause excess demand.

The alternative 'old style' of monetary management accords primacy, instead, to interest rate targets and treats money supply behaviour as incidental. The emphasis on interest rates is a by-product of beliefs about the functions of a central bank which have been held by Bank of England officials for generations. Maintaining interest rate stability lends support to the market 
value of gilt-edged securities, which should also be reasonably steady over time. Gilts are the key to asset values generally. If they are steady, equities and property should be steady, too. This steadiness of asset values is important for the soundness of the financial system. As long as asset values are not rushing wildly upwards or downwards, banks can be confident that their loans have adequate collateral and there is little danger that several of them will become over-extended simultaneously. In this way interest rate stability is a means of ensuring the coherence and integrity of the entire financial system.

'Old style' central bankers did nevertheless, on occasion, contemplate large changes in interest rates. A run on the pound might force an increase in Bank rate to check speculation on the foreign exchanges and to sustain the exchange rate. In extreme emergencies the stability of the exchange rate had higher priority than the steadiness of asset values. A rational justification for this worship of the exchange rate might lie in the role of a fixed exchange rate in forcing a country to adopt and persevere with responsible antiinflationary monetary policies. However, the external value of sterling was typically seen as the ultimate arbiter of foreign 'confidence' in Britain and an essential component of national prestige, and it still holds this status in market gossip.

The sanctification of sterling by the 'old style' is regarded by 'new style' central bankers as little better than superstition. To them interest rates are principally devices for guiding the demand for and supply of credit in domestic financial markets. They concede that interest rates may have a subsidiary function in influencing international capital flows, but they believe that the exchange rate should be governed, first and foremost, by demand and supply in the foreign exchange markets. If hostile pressure builds up against the sterling exchange rate, the right response is to drop the exchange rate until it is realistic.

Has the 'old style' fallen out of favour? And, if so, why? The crucial flaw in the 'old style' was exposed in 1972 and 1973. The floating of sterling in June 1972 weakened the external constraint on monetary policy and enabled the Bank of England to pursue its traditional policy of interest rate stability more or less without regard to the state of the pound. At the same time the Government began to run a huge budget deficit on a scale quite unprecedented in peacetime.

The coincidence of a large public sector borrowing requirement (PSBR) and a new interest rate permissiveness set the scene for an explosive growth in the money supply. The Bank of England seemed bewildered by the rapid increase and attributed it to an institutional adjustment in the wake of Competition and Credit Control. Its arguments, which had always seemed a little contrived, became totally implausible in late 1973. Lax monetary and fiscal 
policies led to a colossal balance-of-payments deficit. After a particularly bad set of trade figures in December 1973 a 2 per cent jump in Minimum Lending Rate (a neologism for Bank rate) became necessary. High interest rates ruled for another year. As 'old style' central bankers would have expected, the result was a collapse in asset values and serious worries about the solvency of many City of London institutions.

But, once the genie of financial irresponsibility had been let out of the bottle in 1971 and 1972, the troubles were inevitable. The scale of monetary disequilibrium in late 1973 was such that a crisis of financial solvency could have been avoided only by allowing a take-off into hyper-inflation. Interest rate stability may be a sensible policy if the price level also is fairly stable and if governments balance their budgets. But it is altogether misguided once the inflationary process is under way and gathering momentum. Interest rate stability is then not even a recipe for keeping asset values steady, because inflation causes a re-assessment of the attractiveness of different assets. If gilt prices are artificially supported by official purchases, the Bank of England may find itself financing a runaway speculative boom in reputedly inflation-proofed assets such as property.

In the present condition of the economy, with high and volatile inflation which is forecast to last indefinitely into the future, a money supply target is much more sensible than a dogged commitment to interest rate stability. The target should be related to prevailing inflation expectations, being set a few percentage points beneath the going rate of inflation. In due course this should bring inflation down without disturbing financial markets more than necessary. Equally, the use of interest rates to buttress a particular exchange rate is folly, when inflation rates in Britain are out of line with those abroad. The adjustment should instead take place through a downward float of the exchange rate. A rigid adherence to a particular exchange rate, whatever its symbolic appeal, might destroy several soundly-based financial institutions, and have subsequent needlessly severe effects on output and employment.

To conclude, the pressure of events over the last four years has prompted a re-appraisal of methods of monetary management by the Bank of England. A 'new style' has emerged, not so much because intellectual arguments convinced policy-makers of its virtues as because the disarray created by the alternative 'old style' obliged the authorities to adopt new approaches. However, the conversion will be complete only when the Bank of England acknowledges money supply targets in the same way as the West German Bundesbank and the American Federal Reserve. The readiness of Bank economists to quibble with 'monetarism' should also give way to a more open recognition of the inadequacy of interest rates as target variables in present conditions. 


\section{Money Supply Targets vs Fixed Exchange Rates}

From an article 'A conflict of objectives in the Government's monetary policy' in The Times, 19 January 1976.

This article foreshadowed many of the controversies of the next 15 years. Taking its cue from Keynes's Tract on Monetary Reform (published in 1923), it argued that a money supply target (i.e., a monetary policy focused on the internal price level) might sometimes be inconsistent with a fixed exchange rate. The point was to criticize a statement in Mr Healey's letter of application to the International Monetary $F$ und (IMF) for a stand-by facility. This statement had been that interest rates were set in relation to 'external as well as domestic objectives', which seemed to me 'useless' and muddled. The themes of the article recur in other papers here, notably in the inaugural lecture to Cardiff Business School in 1990. The comment that a fixed exchange rate leaves 'internal inflation and employment objectives at the mercy of foreign central banks' would, of course, have been equally relevant ten or 15 years later in the the debate about Britain's attitude towards the European Monetary System (EMS).

A money supply target and a fixed exchange rate are incompatible. Indeed, the point is more general than that. Any monetary policy geared to the requirements of the domestic economy is inconsistent with a concern for 'external factors', whether these be the rates of inflation or the levels of interest rates abroad. It would encourage confidence in the British Government's monetary policy if it would recognize these tensions in official policy statements. Because it is not clear at present what objective the Government is pursuing, financial markets have difficulty interpreting policy moves and unnecessary instability is engendered.

The argument is readily developed by looking at the influences on monetary growth. Nowadays cheque payments are many times larger than payments in notes and coin, and the money supply consists predominantly of bank deposits. Deposits are, of course, sums of money owed by the banks to their customers. Deposits on the liabilities side of the balance sheet increase whenever banks are able to expand their assets by lending more. Three main influences on monetary growth can therefore be identified - more lending to the private sector, more lending to the Government (or other public sector agencies) and more lending overseas.

The role of overseas lending, and other external contributors to monetary growth, can be extremely complicated. But some definitional ideas are easy enough to explain. When a country runs a balance-of-payments surplus, it increases its claims on the rest of the world. If some of these claims are 
registered in the banking system, the money supply rises. In particular, when the exchange rate is fixed, the central bank is almost continually active in the foreign exchanges, buying or selling the currencies of other nations. Consequent changes in its foreign exchange holdings can have a significant effect on the money supply. It is only in a system of purely floating exchange rates that no such official operations are conducted and no such impacts on the money supply are possible.

This analysis is the essence of the claim that a fixed exchange rate conflicts, inevitably and necessarily, with a money supply target. It demonstrates that floating exchange rates are required if countries are to have fully autonomous monetary policies. However, external considerations can intrude on domestic policy-making even if the exchange rate is floating. The possibility arises because the central bank may alter interest rates in response to events abroad. These changes in interest rates may repercuss on the avowedly domestic influences on monetary growth, namely bank lending to the private and public sectors.

In the British context the Bank of England may change Minimum Lending Rate (the old 'Bank rate') because of 'the state of the pound'. Through familiar mechanisms, monetary growth is then affected. Consider, first and most simply, bank lending to the private sector. In their borrowing behaviour companies and individuals are plainly concerned about the costs involved. If interest costs are excessive they are deterred from incurring new debt. Secondly, interest rates have a powerful, if more indirect, effect on bank lending to the public sector. Sales of new government debt (or 'gilt-edged securities') to the non-bank public are undoubtedly related to the level of interest rates. The higher are interest rates, the lower is the price of gilt-edged securities and the more gilts the Bank of England can sell. As a result, the Government's deficit (also known as the 'public sector borrowing requirement') can be financed to a smaller extent from the banking system and money supply growth is contained.

Some dealers in the gilt-edged market argue that the Bank of England can sell gilts only 'on a rising market', that is, when interest rates are falling. They go on to assert that increases in interest rates do not boost official gilt sales. Taken to extremes, this piece of market lore becomes absurd, as it would imply that the Bank could attract buyers now if it reduced interest rates to 5 per cent or even 2 per cent. Given present inflation rates, that is clearly not correct. There is a grain of truth in the 'rising market' argument namely, that gilt sales are easier to make if interest rates are expected to decline. But expectations of a decline in rates should be stronger the higher their current level.

There is no real doubt about the link between interest rates and money supply growth. High interest rates dampen monetary expansion and low 
interest rates stimulate it. Clear confirmation of the link, and an emphatic refutation of the 'rising market' argument, has been provided in recent months. The jump in Minium Lending Rate in the autumn enabled the Government to conduct a massive gilts selling campaign in November and December, which has now been fully reflected in the money supply figures.

The undeniable connection between interest rates and monetary growth has a vital implication. If interest rates are used for purposes other than the attainment of money supply targets, those targets may be missed. In particular, if interest rates are raised whenever the pound comes under pressure in the foreign exchange market, the rise in rates interferes with domestic monetary policy.

Suppose, for example, that the money supply is growing at 3 per cent a year while the target is 7 per cent, but that the pound at a $\$ 2$ exchange rate is being sold heavily on the foreign exchanges, even though the Bank of England is committed to a $\$ 2$ exchange rate. Since the pound is being pushed down, external factors indicate the need for higher interest rates. But, obviously, an increase in interest rates would reduce money supply growth further and make it depart even more from the 7 per cent target. Domestic and external objectives are on a collision course.

Although the defence of sterling may cause slow output growth (or falling output) and more unemployment, supporters of a fixed exchange rate sometimes claim that it is needed as 'a discipline'. Because a particular numerical ratio, $\$ 2.80$ to the pound, $\$ 2.40$ to the pound, $\$ 2.00$ to the pound, or whatever, acquires an aura of inviolability if it lasts for several years, it is said to act as an effective obstacle to a spendthrift and inflationary government. In the circumstances of post-war Britain this may be a valid point. But it is a comment on politicians, not a technical proposition in international monetary economics. Quite apart from its disciplinarian hairshirt connotations, the statement that a $\$ 2$ parity would act as an obstacle to inflation is equivalent to the statement that the British Government has to be as financially responsible as the American Federal Reserve decides. More succinctly, to adopt a fixed exchange rate is to abandon the independence of monetary policy. It leaves internal inflation and employment objectives at the mercy of foreign central banks.

The consistent approach to monetary policy is to combine a money supply rule with floating exchange rates. The purer the float, the more consistent the policy. Mr Healey's recent letter of application to the International Monetary Fund contained the statement that interest rates policies 'are formulated with regard to external as well as domestic objectives'. This is useless. It leaves financial markets completely in the dark as to which objective is uppermost in the authorities' minds at any particular moment. 
It will no doubt be said, as if it were a smear, that the combination of a money supply rule and a floating exchange rate is 'monetarist'. That label may be justified, but, if so, Keynes was a monetarist before it became fashionable. Indeed, the classic statement of the potential incompatibility between foreign and domestic monetary objectives is given in Keynes's Tract on Monetary Reform, published in 1923. In its words, the exchange rate "cannot be stable unless both internal and external price levels remain stable. If, therefore, the external price level lies outside our control, we must submit either to our own internal price level or to our exchange being pulled about by external influences. If the external price level is unstable we cannot keep both our own price level and our exchanges stable. We are compelled to choose.'

It is a pity that, after 50 years of muddle and confusion, the British Government still has not chosen. 